\title{
A CAMP FOR SCHOOLCHILDREN IN THE KAFUE NATIONAL PARK, NORTHERN RHODESIA
}

\section{By Erica J. Critchley}

A long required and most urgent need in the education of the "Children of the Country" is being made possible by the generosity and far-sightedness of the Ndola Lottery Board Committee. They have made a grant of $£ 5,000$ to our Game Preservation and Hunting Association for the construction of a permanent camp in the Kafue National Park.

Since our Association started in 1953, parties of school children have been taken on educational visits, by our branches, during the one holiday period that the park is open. These visits have varied in number because of the expense involved. The distance to be travelled from any centre to the "Paradise of the Wild" is never less than $\mathbf{2 5 0}$ miles, in many cases it is more.

The limited staff of the Kafue National Park have each year " made time" to erect attractive grass huts for our use, but more than the huts they were unable to supply. That meant that each branch organizing a school party had to take with them literally everything-mattresses, mosquito nets, blankets, cooking pots and pans, plates and cups, knives, forks, and spoons, baths and basins, waterbags, medical equipment, servants, food and the children. Branches unfortunately had occasionally to cancel a visit, owing to the great cost of each expedition. I say unfortunately, because for three years our Association enjoyed a $£ 500$ grant from our Northern Rhodesian Government, but owing to "financial stringency" they saw fit to discontinue it.

Now with our Camp fully-equipped, all that needs to be taken are the children and the food.

The Ministry of Education has agreed that children in parties of twelve, accompanied by a teacher, may attend the course at the Camp during term-time. This decision is most welcome and appreciated by our Association because, due to our climate in Northern Rhodesia, the Kafue Park is only open during the months June-November, and during that period only the August school holidays occur.

The Course is for five days, one day will be spent in getting to the Camp and another in returning.

It is planned that a permanent lecturer will be at the camp, and a most excellent syllabus has been prepared by the warden.

The camp is situated in an area where woodland savannah 
merges into plain and finally swamp. There is a fine variety of fauna within a short distance. The design of the camp will make full use of the natural trees and termite hills, all buildings will have thatched roofs, and we hope, if not too costly, that the children will have three big " roundavels" for four beds each, rather than a great ugly dormitory.

There will be a fully-equipped lecture hall with photographs of animals and birds, museum collections of skulls, spoor casts, faecal material, plant specimens of important food material. Library books covering birds, mammals, fishes, reptiles, amphibia and trees will be supplied, also a slide projector and collection of slides.

Mr. Gibbs of the American Conservation Foundation and Mr. Lara of the National Wildlife Federation in America are being most generous in sending us their educational literaturean important gift to a country which possesses practically none of its own. It may surprise readers in England to learn that in a new country, such as ours, whose civilized history cannot go back more than 60 years (and within the last 35 years wild animals were in their hundreds on the farms) that there are today, in the towns, children both white and black, who have never seen a wild animal. And more surprising, our own African house servants, grown men, whom we take into the wilderness areas from time to time, have never seen an eland, a hartebeeste, a waterbuck, much less a lion or a majestic elephant.

If these people of our country after only 60 years of so-called "civilization" are allowed to be so ignorant of the wonders of nature, how, without such a camp as a small beginning, can we expect them to realise and value the magnitude of their inheritance-the Unique, Wonderful and Beautiful Fauna of Africa?

Education, not only of the children but of adults, is of crying importance, We have given film shows and talks to Native Authority groups and to one African political party. The latter show was an unqualified success; the Africans were interested beyond belief in the new concept of the value of the fauna both as a tourist attraction and as a source of protein, asking many pertinent questions, and demanding more and more literature. At the end, our president stressed the unique value of their inheritance-The Fauna-and told how the rest of the world were most envious of them for possessing it. The Africans were quite delighted, and in reply their leader said, "You are not to kill the animals, not even a rabbit, until we can learn more about this new idea, the value of the Fauna." 
'To think that adults and children, of any colour or creed, can live in African countries and never hear the wonderful "calls in the night"- the hippo grunting, the baboon barking, the " coufh" of a passing leopard, the spirit-stirring roar of a lion, the dawn chorus of the birds. Unless more is done, and done quickly, many of these people will grow only to recognize the "call" of the automobile, the dance tunes, the human voice, and the smell of civilization.

\section{QUESTIONS IN PARLIAMENT}

The following extract is taken from The Times of 22nd March, 1961 :-

\section{Protecting African Wild Life \\ More Effort Needed}

Mr. Callaghan (Cardiff, South-East, Lab.) asked the Secretary of State for the Colonies, what steps were taken by the Northern Rhodesian Government to spread knowledge among Africans and others of the need for conservation of wild life in the territory ; and what financial support was given to the organizations working for this purpose.

Mr. Hugh Fraser, Under-Secretary, Colonial Office (Stafford and Stone, C.): The Northern Rhodesia Government spread this knowledge through lectures, broadcasts, and films. Although no direct financial support is given to game preservation organizations, they are assisted by the provision of access roads, sites, and other services in the Kafue National Park.

Mr. Callaghan: Is the Under-Secretary aware the present policy is quite unsatisfactory? Would he please review it in the light of the recent report by Dr. Fraser Darling, in view of the fact that proper conservation of wild life would yield a substantial meat diet to Africans, whereas indiscriminate slaughter going on at present is likely to lead to hunger in a very short time, quite apart from the destruction of wild life ?

\section{Autumn Conference}

Mr. Fraser : It is true to say that in the last ten years there has been considerable progress and expenditure. What is more, this autumn we will be in touch with the International Union for the Conservation of Nature and also the Commission for Technical Co-operation South of the Sahara. In September there will be a conference at Arusha to discuss these matters on an international basis. I agree we ought to do more, as the Northern Rhodesians propose to do within Northern Rhodesia. 
Sir Godfrey Nicholson (Farnham, C.) : Will the Minister read Dr. Fraser Darling's report and his books, and then I think he will not be so happy about it? Complete extinction of native African fauna is changing from a possibility to a probability ? It is largely due to poaching, when the utmost cruelty ensues, that game is becoming extinct, to the detriment not only of the diet of the Africans but largely to the future of the tourists trade as well.

Mr. Fraser : We are aware of these facts. That is precisely why we are holding this conference at Arusha in the autumn. 